This is an Accepted Manuscript of an article published by Taylor \& Francis Group in Journal of ethnic and migration studies on 25/10/2016, available online: http://www.tandfonline.com/10.1080/1369183X.2016.1249048

This Version 15 February 2016

\title{
Drivers of Highly Skilled Mobility from Southern Europe: Escaping the crisis and emancipating oneself
}

\author{
Laura Bartolini * \\ Ruby Gropas ** \\ Anna Triandafyllidou * \\ * European University Institute, Florence, Italy \\ ** Democritus University of Thrace, Komotini, Greece and College of Europe, Bruges \\ Corresponding author: laura.bartolini@eui.eu
}

\begin{abstract}
Since the outbreak of the crisis in southern Europe, growing numbers of young highly educated Italians, Spaniards, Portuguese and Greeks have been taking their talents and expertise to other countries in search of a better quality of life and career prospects. There is limited knowledge on the characteristics of these new emigrants, the reasons for which they are leaving, and whether these reasons are shaped by the economic crisis, by pre-crisis grievances, or by other factors. The paper seeks to answer these research questions by analysing original data from 6,377 questionnaires collected in four countries through an esurvey run in 2013. We refer to the existing literature on the drivers of highly skilled emigration and the (un)employment situation in the four aforementioned countries. We explore the features of these new highly skilled emigrants, and the reasons that led them to leave their countries of origin. We suggest that while gender is not important, age, marital status, education and satisfaction with current employment (both income related and with regard to future prospects) are important factors predicting emigration. Non-economic factors, notably career opportunities, quality of life, and future prospects supersede all other considerations in the decision to emigrate for these highly educated Europeans.
\end{abstract}

Keywords: highly skilled migration, mobility, economic crisis, Southern Europe, emigration 


\section{Introduction}

Since the outbreak of the crisis in Southern Europe, growing numbers of young, highly educated, qualified and skilled southern Europeans have been taking their talents and expertise to other countries in search of better funds, career opportunities and payoffs. The economic and political crises in these countries, the austerity measures and rampant unemployment rates and the dramatic decreases in salaries and welfare allowances, have pushed young Southern Europeans to "vote with their feet", leaving for other countries or continents. The departure of southern Europe's highly educated youth in particular has been described as potentially one of the harshest consequences of the crisis, triggering alarmed public debates as to the medium and long term consequences of this flight of brains at a time where innovation and creativity are critical for these economies to start growing again.

Young, educated women and men from Greece, Italy, Spain and Portugal have been experiencing several years of financial and economic distress in their respective countries. As a result, they have been seeking to make their transition from study to work and to build their professional life amidst collapsed labour markets, economic recession, sharply rising poverty and inequalities, as well as restricted professional development opportunities.

This has been taking place against a wider background of increasing individualization of life and work careers (Giddens 1991; Beck and Beck-Gernsheim 2002), growing competition and uncertainty of a globalized world (Blossfeld et al. 2015), and a changing world of work due to what is being increasingly referred to as the Fourth Industrial Revolution (Schwab 2016). In an era of high mobility and risk (Beck 1992) individuals who opt to emigrate combine economic rationalism with existential questions about quality of life and realising one's self. Geographical mobility enlarges one's opportunity space: be it a temporary but necessary rite of passage, a long-term decision, or a prerequisite for further upward mobility in the labour market, middle-class youth migration is a salient feature of current times (Frändberg 2015). At the same time, a context of enduring economic depression coupled with the 'institutionalized individualism' of life patterns (Beck and Beck-Gernsheim 2002) frames the decision to emigrate of some southern Europeans as a statement of criticism towards their home societies for repressing or limiting their potential, and as a rational choice to move to where economic and personal development aspirations can be better fulfilled. In effect, recent studies (OECD 2013b; Papademetriou 2015) have highlighted that the new Southern European emigrants have been motivated particularly by expectations for better career prospects and quality of life at destination.

This paper contributes to the growing literature on emigration from Southern European countries during the crisis period, looking specifically at the reasons and drivers for emigration of highly skilled Southern Europeans. In the sections that follow, we first present some background information on the labour market conditions and emigration trends in Europe and specifically in Italy, Greece, Spain and Portugal in the last years. After discussing the literature on the drivers of highly skilled migration to highlight the relevance of both economic and non-economic motives on individual choices, we present our research 
questions. We then turn to the presentation of the data collected through an e-survey conducted in 2013 to examine the profiles of emigrants from Southern Europe and to highlight changes in the motivations and drivers for migration between those who migrated before and those who migrated after the economic crisis in Europe. The final section of the article synthesises our empirical findings and proposes avenues for further research.

\section{Low Mobility In Spite of High Unemployment}

Europe's youth is hit particularly hard by the ongoing crisis and the situation is far more acute in the southern EU member states. In September 2015, 4.5 million young persons (under 25 years of age) were unemployed in the EU28, 3.1 million among these were in the euro area (Eurostat 2015). Although slightly improving on average, youth unemployment rates are generally higher and have increased more than unemployment rates for all ages during the crisis. In September 2015, youth unemployment rates stood at 20.1\% in EU28 (22.1\% in the Euro area, down from $24.5 \%$ of September 2013). These average rates however hide marked disparities between different member states. While some Central and Western European countries show quite constant youth unemployment levels throughout the crisis (notably Germany, Austria, Denmark, and the Netherlands), youth unemployment was at $47.9 \%$ in Greece, $46.7 \%$ in Spain, 40.6\% in Italy and 31.2\% in Portugal in September 2015. Moreover, while the relative increase from the beginning of the crisis has been null (Germany, the UK) or moderate in most of western and eastern EU countries, the differences between January 2008 and September 2015 in youth unemployment rates is more than 10 percentage points in Portugal (10.4\%), Ireland (10.5), Croatia (19.8), Cyprus (22.1), Spain (26.5) and Greece (27.3) (Eurostat 2015a).

Despite these striking unemployment rates and although EU statistics indicate that work is the prevalent reason for EU citizens moving to another EU member state (EY 2014, 12), intra-EU mobility remains a limited phenomenon (Recchi 2015; Recchi and Salamońska 2015). Notwithstanding the EU efforts to encourage a greater 'European mobility culture', intra-EU mobility remains impressively low even after the accession of new member states in 2004, 2007 and 2013. In 2014, a total of 19.6 million EU nationals were living in another EU member state which amounts to only $2.8 \%$ of the EU population for that year (Eurostat 2015a).

Although incentives aimed at fostering greater intra-EU mobility have kicked off well especially in the education area (through the ERASMUS, LEONARDO and SOCRATES programmes, today brought together by the Erasmus+), there remain important obstacles (associated with bureaucratic and administrative hurdles, degree recognition, transfer of welfare benefits as well as practical challenges such as language) that hamper true and easy intra-EU mobility of both EU and third-country nationals (European Commission 2013). Perhaps more importantly however, although EU citizens value free movement, only 17\% 
envisage working and living abroad according to a 2010 Eurobarometer report on geographic and labour market mobility (European Commission 2010).

The recent economic crisis has reshuffled the distribution of EU migration with adjustments to changing labour market conditions possible through the free movement of workers: outflows from some central and eastern European countries have slowed down, some EU migrants returned or re-emigrated out from the most hard hit crisis countries and the SouthNorth migration route has re-emerged with people from Spain, Greece, Italy and Portugal moving to Northern Europe or outside the EU (O’Reilly et al. 2015).

Data on in- and out- migration from our selected countries are not available by age or education level. Eurostat provides data on emigrants and immigrants by citizenship, through which is possible to distinguish the movements of nationals by those of foreigners. A negative net migration might be due to a decrease in inflows of migrants from abroad as well as to an increase in outflows of both migrants (returning to their origin countries) and nationals (Eurostat 2015b). Figure 1 compares the net emigration rate for the total population and for nationals only. The difference between the two graphs is due to movements of foreigners, and is particularly relevant in the case of Italy and Spain. Indeed, net emigration rates of nationals only are around zero in 2008 and the increase in net emigration rates between 2008 and 2013 seems mostly due to the reversing mobility patterns of foreign workers. Migrant populations in Greece and Portugal instead are less influential on total averages and the increase in net emigration rate is to around $-4 \%$ among nationals.

Figure 1: Net emigration rate, total population (T) and nationals only $(N)$, 2008-2013(\%)
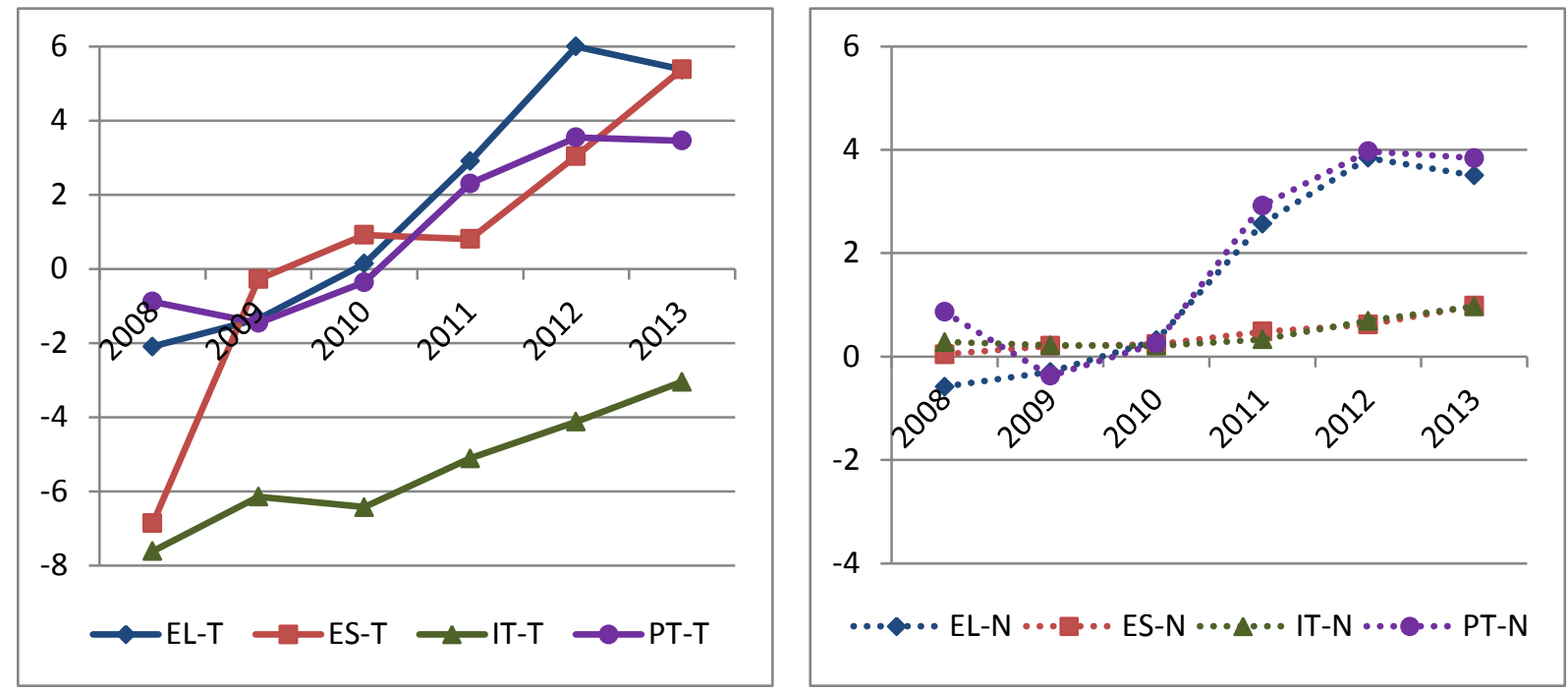

Net emigration rate $=($ emigrants-immigrants $) * 1000$ inhabitants .

Source: Eurostat Database online, 2015 [migr_emi1ctz, migr_imm1ctz].

Trends of emigration and of net emigration in particular - although increasing and bearing in mind that official figures might under-estimate the phenomenon - are not moving as fast as 
unemployment rates are deteriorating. Figure 2 compares the difference between unemployment and emigration rates between 2008 and 2013 on total population and nationals only.

Figure 2: Change in unemployment and net emigration rates between 2008 and 2013, total population and nationals only (\%).

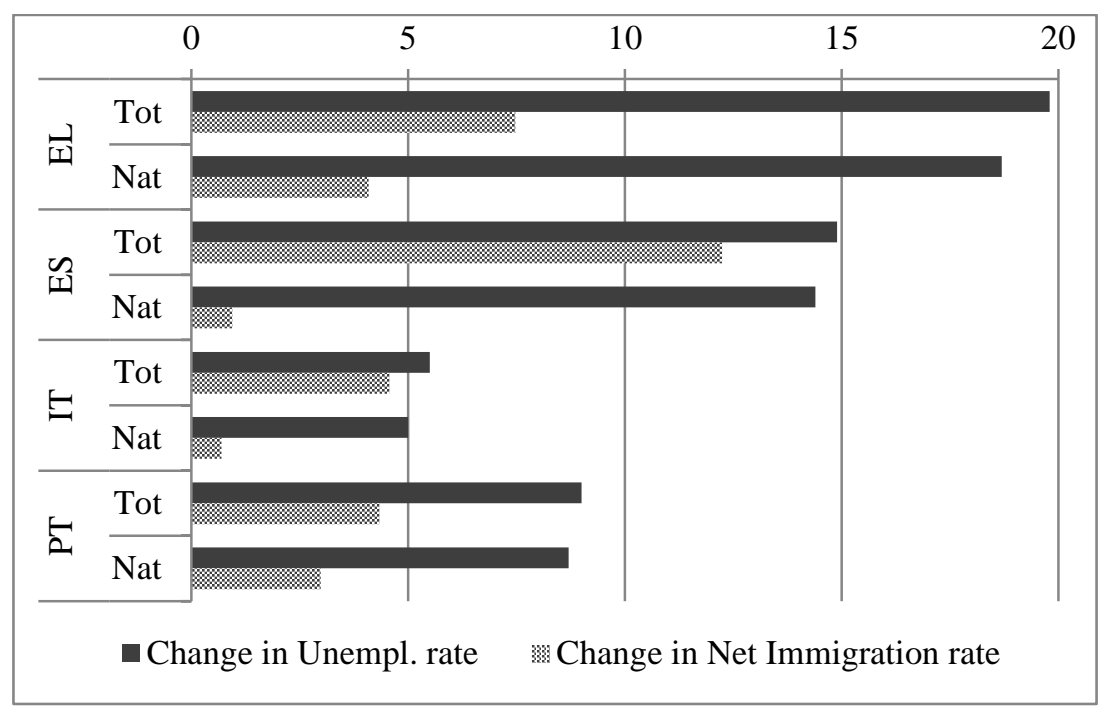

Source: Eurostat Database online, 2015 [migr_emi1ctz, migr_imm1ctz, lfsa_urgan].

Although there has been a striking increase in unemployment between 2008 and 2013 in all four countries, from the 18.7 percentage points of Greece to the 5 percentage points of Italy, the increase in net emigration among nationals is lower than could be expected. While foreigners seem to be departing from Spain, Spanish nationals emigrate less than Greek ones (0.9 versus 4.1 percentage points of increase) although they share a comparable increase and level of unemployment over the past years.

Focusing more specifically on highly-educated people, we are confronted with a significant scarcity of comparable data which makes it challenging to discuss the relationship between the growth of unemployment rates and the related increase in net emigration. The Database on Immigrants in OECD Countries (DIOC) 2010/2011 (OECD 2013a) is the only source of comparable estimates of emigration rates by education level. According to these data, the strongest growth in emigration rates between 2000 and 2010 was experienced by Europe and Latin America (Arslan et al. 2014: 37) and the share of tertiary educated among migrant women is higher than among migrant men in many countries (Arslan et al. 2014: 45). In particular, patterns of emigration vary consistently across our countries of interest: Portugal is among the countries with the highest total emigration rate and highly-skilled emigration rate (both at about 14\%). Spain on the other hand shows a particularly low level of emigration (Table 1) with Greece and Italy standing in between. Interestingly, although the labour market 
situation in 2010-2011 was much worse in Greece compared to Italy, the emigration rate of the highly skilled was higher in the latter and overall emigration rates in Greece were spectacularly low (lower actually than ten years earlier). In the following sections we try to cast light to the puzzles emerging from these figures, notably why are highly skilled southern European emigrating and what are the factors influencing their decisions and actions.

Table 1: Emigration rate by country of birth (age 15+), total and highly-skilled.

\begin{tabular}{l|rr|rr}
\hline & \multicolumn{2}{|c|}{$\begin{array}{c}\text { Emigration rates 2010-2011 } \\
\text { Total }\end{array}$} & $\begin{array}{c}\text { Emighly- } \\
\text { Skilled }\end{array}$ & \multicolumn{2}{c}{$\begin{array}{c}\text { Total } \\
\text { Highly- } \\
\text { Skilled }\end{array}$} \\
\hline Greece & 6.6 & 5.9 & 6.9 & 7.6 \\
Italy & 4.3 & 8.4 & 4.6 & 6.2 \\
Portugal & 14 & 14 & 12.8 & 8 \\
Spain & 2 & 2.1 & 2.5 & 2.5 \\
\hline
\end{tabular}

* estimates based on BL dataset (Barro and Lee 2013)

Source: DIOC 2010/2011 (Arslan et al. 2014: 59-61)

\section{Between copying strategies and life aspirations: pieces of the same puzzle}

Emigration generally comes as an individual or household strategy to improve one's condition in academic, professional, financial or personal terms. Motivations for Southern European migrants might well be framed along the classical lines of economic, demographic, environmental and security factors which are recurrent in the literature of international migration (Massey et al. 1993). The accumulation of cultural capital tends to also be a particular consideration in the case of young and highly skilled workers. Indeed, international education has been a strategy through which to increase 'employability' and secure 'positional advantage' through education (Brown, Hesketh, and Williams 2004; J. L. Waters 2012; Mosneaga 2014; J. Waters, Brooks, and Pimlott-Wilson 2011). Also, the decision to move or migrate is intricately linked with the process of construction and reconstruction of the self of young, highly educated individuals. In the case of young Southern Europeans, their decision to move to another country can represent an 'escape' to cope with a stagnating situation, a search for employment opportunities (current or in the future) but also a desire for exploration, discovery and experimentation whether in career or personal terms.

Studies on Southern Europe (Jauer et al. 2014; Gropas and Triandafyllidou 2014) find that males, younger people and more educated ones are more likely to migrate than women, older and less educated persons. In addition, unemployment in the country/ region of origin is neither the only nor the main cause of emigration (ibid.). Indeed, those who are unemployed and lower skilled are more likely to be stuck into a localised unemployment trap and may not be responsive to regional labour market disparities, while the more educated might be more 
likely to choose between being over-qualified for occupations available at home and migrating to find better opportunities.

Out-migration of the highly skilled from these countries is not a new phenomenon. Labrianidis and Vogiatzis have argued that migration of professionals from Greece could be mostly attributed to the low demand for graduates from the private sector (Labrianidis and Vogiatzis 2013, 474), even before the crisis outbreak. A similar situation can be noted in the case of Portugal and to a lesser extent Italy and Spain, although the phenomenon is relevant for the EU well beyond its southern member states.

The expectation that future employment and wage prospects and opportunities at destination will be better than in their home country has long been acknowledged as a core determinant in an individual's cost-benefit analysis when making the decision to migrate. Similarly, the highly selective nature of migration has also been long underlined, as individuals with better labour market perspectives and high levels of human capital are more likely to migrate (de Grip, Fouarge, and Sauermann 2010; Fratesi and Riggi 2007). Indeed, if Southern EU labour markets are structurally not able to absorb the highly skilled professionals they themselves educate (through public universities) largely due to the lack of investment (both public and private) in high tech and innovative economic sectors, the overall EU shortages of skilled workers in engineering, science, technology and mathematics is also a growing concern (Campanella 2015).

As the attractiveness and capacity of absorption of high professionals is weak across the EU and particularly so in Southern Europe, the choice for highly skilled southern Europeans seems then a binary one between a more limited employment at home (in terms of skill requirement, level of responsibility, career development and professional opportunities) and wider, potential employment and career prospects abroad. Among the highly skilled, scientists and engineers tend to be the most mobile due to the international transferability of their knowledge and the fact that they are usually 'wanted and welcome' migrants thanks to their contribution to economic innovation and the development of new technologies and products (Fassio, Kalantaryan, and Venturini 2015; Fassio, Montobbio, and Venturini 2015).

Economic studies on highly skilled migration have concentrated on wage and other workrelated differentials, as well as on more 'qualitative' labour market incentives such as utilisation of skills or involvement in research and development. More qualitative research has emphasised the importance of career prospects in migration decisions. Non-monetary drivers such as the ability to achieve a better skill match on the job, the country reputation with regards to the prospects offered by its labour market (in terms of openness, meritocracy and potential for upward professional mobility), and the potential for intellectual achievement constitute strong drivers for migration especially in the cases of scientists and engineers (de Grip, Fouarge, and Sauermann 2010). More specifically, finding a 'better' job match seems to matter more than specific wage gains in the decision to migrate for IT and engineering professionals (de Grip, Fouarge, and Sauermann 2010). 
Relevant for the decision to migrate is also the existence of past periods abroad. Internships or student exchange schemes may be beneficial in terms of gaining experience in personal and academic development, and in decreasing the costs of future migration through the acquisition of transnational and transversal skills: speaking another language, learning how to settle and adapt in a new environment, enlarging social networks in a multicultural way (Parey and Waldinger 2011). At the same time however, some concerns have been raised as regards the increasing risk of brain drain from southern to northern Europe (Mathiassen 2014; Raffini 2014; Souto-Otero et al. 2013). Recent studies (Cairns 2014; Labrianidis 2014) suggest that the question of who moves and who does not move is ultimately related to social class and family background so that there are good reasons to expect that youth from less privileged backgrounds may be less mobile, but also that when they do engage in intra-EU mobility their decision may be framed more as a matter of need rather than a lifestyle or career choice.

In light of the above considerations and earlier findings on the drivers of highly skilled migration, this paper delves into the motivations and factors behind the decision to move for a specific group of individuals originating from four Southern European countries. Our focus is on Greece, Italy, Portugal and Spain as they share some interesting structural features in terms of labour market structure and mismatch between education and production systems (ILO 2015; ILO 2014) as well as some comparable contingent economic trends over the last years, especially since the outbreak of the economic crisis in 2008. In this context of contrasted pressures, notably high unemployment (particularly among young people) and difficult studyto-work transitions on one hand, and a culture of low mobility in Europe on the other, our paper offers some new insights as to what drives the migration decisions of highly skilled individuals. And, if some recurrent patterns of emigration among young, highly-skilled emigrants from Southern Europe can be depicted, we also ask whether the context of prolonged economic crisis has magnified the interplay between the traditional reasons for emigration and more contemporary pressures of increasingly global and mobile employment conditions.

\section{New empirical data on Highly Skilled Migration in Times of Recession}

The analysis presented in this paper is based on data collected through a quantitative survey on Highly Skilled Migration in Times of Crisis (XX) run in 2013 to capture emigration from the crisis countries. This e-survey was launched in five languages (English, Greek, Italian, Portuguese and Spanish) and disseminated through newspapers, social media and other institutional networks to reach emigrants from southern Europe and Ireland, in order to investigate the profiles and expectations of highly skilled individuals who left from the five countries most severely hit by the economic crisis since 2008. Through self-administered, internet questionnaires, it collected around 6,750 valid responses of people who had already emigrated at the time they responded. 
Although the previously mentioned lack of reliable and comparable official data on emigration patterns from southern Europe has prevented authors from designing a representative sample, this remains the first quantitative survey in Europe on recent outmigration and offers insightful data on a population which is often recalled in public debates but little studied in terms of educational background, economic situation before leaving, motivations and expectations regarding their migratory experience. The survey also captures the newest waves of emigration (up to the first half of 2013), avoiding the time lag of administrative records and national statistical offices, and covers a wide geographical range in terms of origin and destination countries: the original dataset includes Greek, Irish, Italian, Spanish and Portuguese respondents who had moved to over 100 different countries around the world, from Switzerland to the UK, from Canada to Australia, from Brazil to the United Arab Emirates and Angola. For the purposes of this article, we selected only Greece, Italy, Portugal and Spain. Our sample is therefore composed of 6,377 individuals, with a fair age balance (44\% below 30 years of age), prevalently with a tertiary education degree (88\%) and male (62\%), who migrated after the beginning of the economic crisis in all their origin countries (74\% emigrated since 2009). In doing so, although we cannot compare emigrants with their non-emigrant peers, our aim is to single out the different conditions before departure and the drivers for emigration of young highly-skilled individuals who left before and during the economic crisis. In the sections that follow we present some general characteristics about the sample focusing mainly on educational background and employment status prior to migration.

\section{Sample structure, basic characteristics and preferred destinations}

The survey collected data about the main socio-demographic and educational features of respondent emigrants, their situation prior to emigration, their family dynamics, the reasons for leaving their home country, the main problems faced at destination. Quantitative information is also complemented by open-ended questions on subjective evaluations of the emigration experience, on future prospects and on the comparison between the host and the origin country. 
Table 2: Sample structure by sex and country of origin

\begin{tabular}{|c|c|c|c|c|c|c|c|c|c|c|c|c|c|c|c|c|c|}
\hline & & \multirow{2}{*}{\multicolumn{4}{|c|}{ Greece }} & \multirow{2}{*}{\multicolumn{4}{|c|}{ Italy }} & \multirow{2}{*}{\multicolumn{4}{|c|}{ Portugal }} & \multirow{2}{*}{\multicolumn{4}{|c|}{ Spain }} \\
\hline & & & & & & & & & & & & & & & & & \\
\hline & & \multicolumn{2}{|c|}{ Male } & \multicolumn{2}{|c|}{ Female } & \multicolumn{2}{|c|}{ Male } & \multicolumn{2}{|c|}{ Female } & \multicolumn{2}{|c|}{ Male } & \multicolumn{2}{|c|}{ Female } & \multicolumn{2}{|c|}{ Male } & \multicolumn{2}{|c|}{ Female } \\
\hline & & Freq. & $\mathrm{Col} \%$ & Freq. & $\mathrm{Col} \%$ & Freq. & $\mathrm{Col} \%$ & Freq. & $\mathrm{Col} \%$ & Freq. & $\mathrm{Col} \%$ & Freq. & $\mathrm{Col} \%$ & Freq. & $\mathrm{Col} \%$ & Freq. & $\mathrm{Col} \%$ \\
\hline \multirow{3}{*}{ Age classes } & $<30$ & 291 & 49.2 & 127 & 45.7 & 216 & 33.6 & 86 & 43.4 & 732 & 39.4 & 720 & 51.5 & 341 & 38.3 & 271 & 52.0 \\
\hline & $31-45$ & 281 & 47.5 & 143 & 51.4 & 329 & 51.2 & 101 & 51.0 & 978 & 52.7 & 635 & 45.4 & 420 & 47.2 & 218 & 41.8 \\
\hline & $46+$ & 20 & 3.4 & 8 & 2.9 & 98 & 15.2 & 11 & 5.6 & 146 & 7.9 & 44 & 3.2 & 129 & 14.5 & 32 & 6.1 \\
\hline $\begin{array}{c}\text { Married / } \\
\text { Partnered }\end{array}$ & Yes & 344 & 58.1 & 174 & 62.6 & 414 & 64.4 & 123 & 62.1 & 916 & 49.4 & 630 & 45.0 & 548 & 61.6 & 321 & 61.6 \\
\hline \multirow{4}{*}{ Education level } & No higher education & 86 & 14.5 & 17 & 6.1 & 89 & 13.8 & 7 & 3.5 & 297 & 16.0 & 112 & 8.0 & 119 & 13.4 & 38 & 7.3 \\
\hline & Undergraduate & 162 & 27.4 & 79 & 28.4 & 198 & 30.8 & 51 & 25.8 & 815 & 43.9 & 641 & 45.8 & 122 & 13.7 & 64 & 12.3 \\
\hline & Master & 268 & 45.3 & 146 & 52.5 & 256 & 39.8 & 102 & 51.5 & 618 & 33.3 & 507 & 36.2 & 556 & 62.5 & 366 & 70.3 \\
\hline & $\mathrm{PhD}$ & 76 & 12.8 & 36 & 13.0 & 100 & 15.6 & 38 & 19.2 & 126 & 6.8 & 139 & 9.9 & 93 & 10.5 & 53 & 10.2 \\
\hline \multirow{4}{*}{$\begin{array}{r}\text { Time of } \\
\text { migration }\end{array}$} & $<2009$ & 112 & 18.9 & 58 & 20.9 & 235 & 36.6 & 83 & 41.9 & 485 & 26.1 & 358 & 25.6 & 217 & 24.4 & 114 & 21.9 \\
\hline & $2009-2011$ & 224 & 37.8 & 99 & 35.6 & 199 & 31.0 & 58 & 29.3 & 510 & 27.5 & 451 & 32.2 & 265 & 29.8 & 145 & 27.8 \\
\hline & 2012-2013 & 256 & 43.2 & 121 & 43.5 & 209 & 32.5 & 57 & 28.8 & 861 & 46.4 & 590 & 42.2 & 408 & 45.8 & 262 & 50.3 \\
\hline & Total & 592 & 100.0 & 278 & 100.0 & 643 & 100.0 & 198 & 100.0 & 1,856 & 100.0 & 1,399 & 100.0 & 890 & 100.0 & 521 & 100.0 \\
\hline
\end{tabular}

Figure 3: Field of education, by sex ( $\%$ of higher educated)

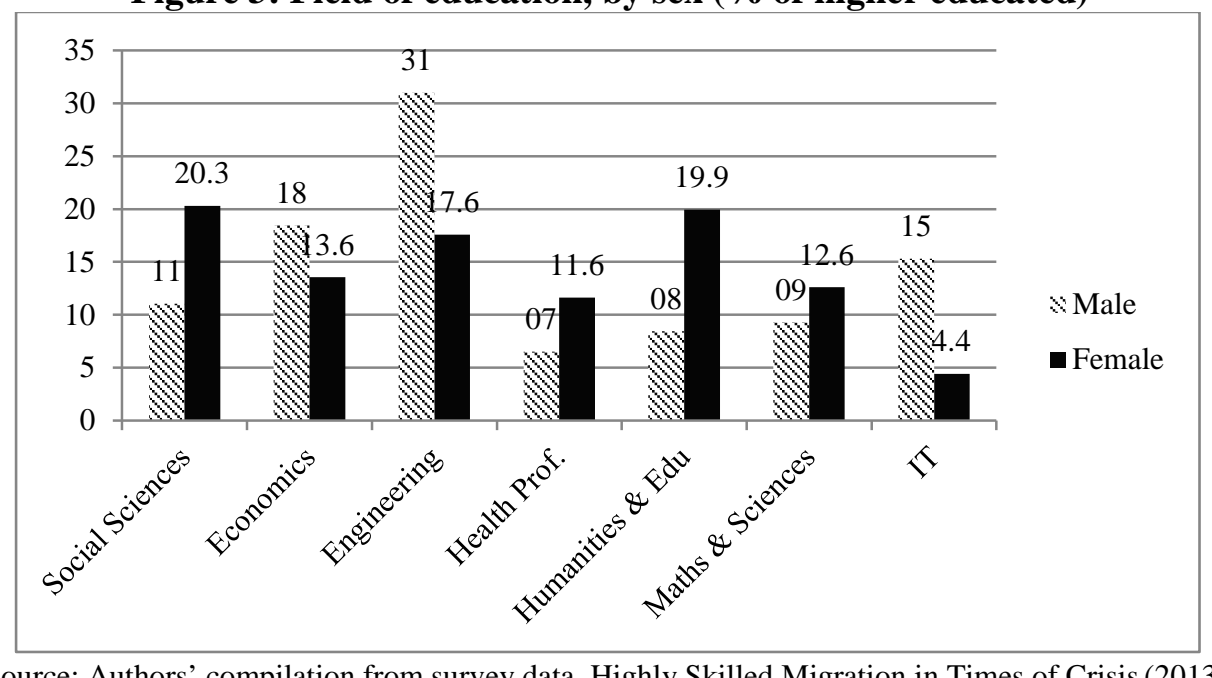

Source: Authors’ compilation from survey data, Highly Skilled Migration in Times of Crisis (2013). 
Females, who represent almost 38\% of our selected sample of 6,377 interviewees, tend to hold educational qualifications higher than men and are over-represented in tertiary education (47\% of Master's degrees and $11 \%$ of $\mathrm{PhDs}$ against $43 \%$ and $10 \%$ among males respectively). Female respondents are also younger than males on average, with half of them being under 30 years of age.

Looking at the year of migration, there are different timings of migration across the surveyed countries. While around 43\% of the total sample stated they emigrated in 2012-2013 and another 31\% stated that they left the origin countries between 2009 and 2011, Italian respondents appear to have a longer history of migration with $37 \%$ of males and $42 \%$ of females having migrated before 2009. This is also testified by their older age structure in comparison to the rest of the sample (Table 2).

As regards their education level (Figure 1), $88 \%$ of the sample has a higher education degree distributed across disciplines and specializations. Engineering and construction represent a quarter of all respondents, with $31 \%$ of males and $17.6 \%$ of females having graduated in these fields. Beyond engineering, males are concentrated in economics (18.5\% of them) and IT (15.3\%). Females instead are more frequently graduated in social sciences (20.3\%), humanities and education (19.9).

\section{Labour market participation before leaving}

Descriptive statistics on the employment situation of respondents before migration help us contextualize their condition before deciding to leave the origin country. More than $60 \%$ of all respondents describe themselves as employed before migration. While the lowest employment rates are those of Spanish and Greek respondents, the Italian sub-sample presents the biggest gender gap in employment rates (21.5 percentage points) and Portuguese males appear to be the most employed overall (70.2\%).

Table 3: Share of respondents (\%) who were employed before migration, by sex and country of origin

\begin{tabular}{lcrrrr}
\hline & GR & \multicolumn{1}{l}{ ES } & \multicolumn{1}{c}{ IT } & \multicolumn{1}{c}{ PT } & \multicolumn{1}{c}{ Total } \\
\hline Male & 50.7 & 52.8 & 68.0 & 70.2 & 63.0 \\
Female & 55.4 & 49.4 & 46.4 & 62.6 & 57.6 \\
\hline Total & 52.2 & 51.5 & 62.9 & 66.9 & 61.0
\end{tabular}

Source: Authors’ compilation from survey data, Highly Skilled Migration in Times of Crisis (2013).

To obtain a better picture of the employment conditions before migration and how these have changed through migration, we distinguish among those not in employment, those employed without a contract, those with a short-term contract and those with a long-term open-ended contract. As shown in Figure 4, the numbers of respondents not in employment (in blue) significantly decreases after migration in all countries. Similarly, workers without a contract (in red) diminish while there is a parallel increase of those employed either with a short-term (in yellow) or long-term 
(in green) contract. Thus, overall, the employment situation of the emigrants appears to have improved compared to their situation before leaving. Nevertheless, there is room to investigate the reasons for moving to explain why also those with a long-term contract migrated and why some of them were no more in employment or with less secure job position at the time of the survey.

\section{Figure 4: Employment status before and after migration (transitions), by country of origin and total}
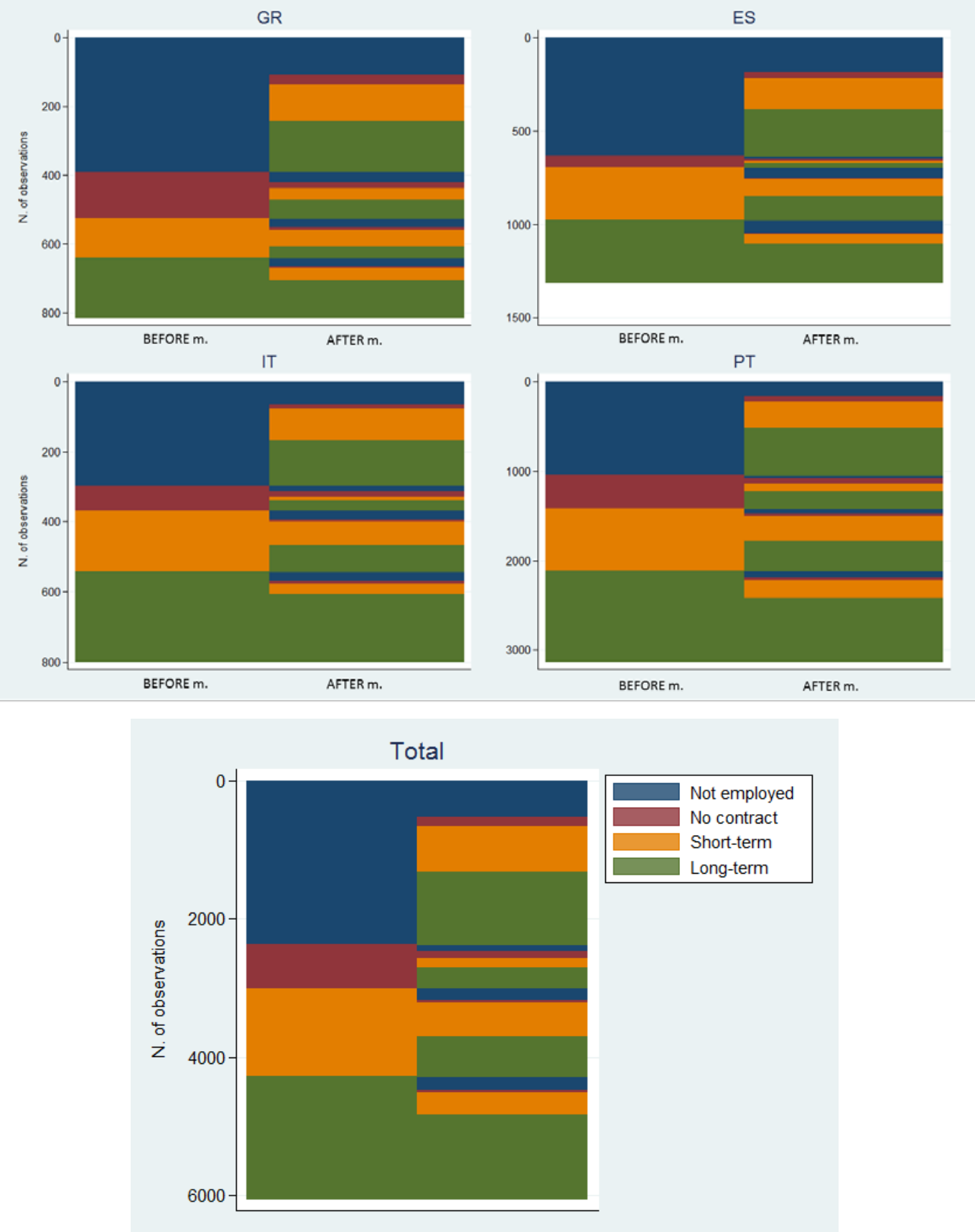

Source: Authors’ compilation from survey data, Highly Skilled Migration in Times of Crisis (2013).

\section{The choice of destination}

A variety of destination countries are referred to in our survey. While approximately $40 \%$ of all respondents live in the UK or Germany at the time of the survey, destination countries named in the 
survey include nearly all EU countries, while $20 \%$ of the respondents live outside the European Union (Figure 5). Moreover, although $80 \%$ of the total sample answered that the actual destination was specifically chosen at the time of emigrating, roughly only one third of respondents stated that the choice of the country was determined by the absence of visa restrictions and the presence of some facilitating factors (in particular having relatives in the destination country, having lived/studied there before, or knowledge of the language).

Figure 5: Destination country by sex

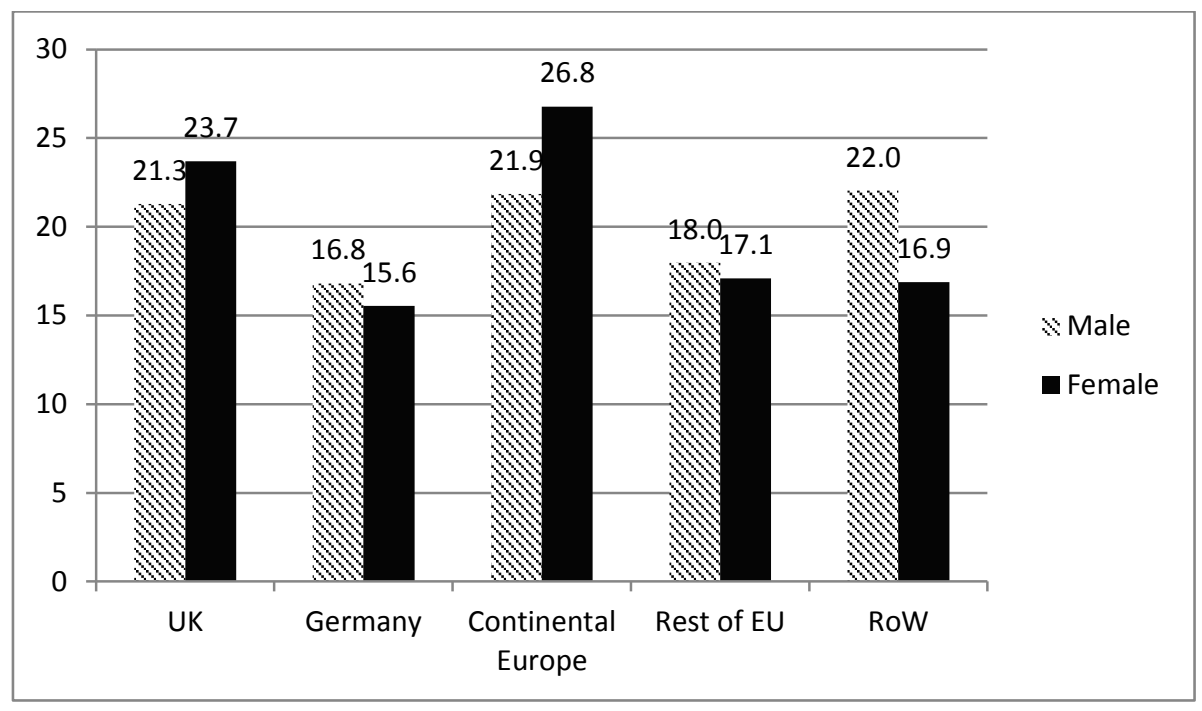

Note: Continental Europe includes, Belgium, France, Netherlands and Switzerland; Rest of EU includes all EU countries with the exception of the UK, Germany, Belgium, France and Netherlands.

Source: Authors’ compilation from survey data, Highly Skilled Migration in Times of Crisis (2013).

\section{Drivers of emigration: investigating the reasons for leaving}

The original survey investigated the reasons for leaving the country of origin with a question which allowed multiple answers between twelve possible options. More than half of the sample ticked more than one option. The correlation between pairs of different reasons is quite low in the majority of cases, so that a principal component analysis (PCA) could not be used as a tool to convert the twelve options into a smaller set of components. Hence, we grouped the original options into five specific groups belonging to three broad areas (Figure 6), namely:

- labour market integration at origin,

- the context at origin for present and future quality of life, and

- personal aspirations and individual development.

Our aim was to check the relative weight of purely economic motivations and actual needs (to increase income or to improve job situation), compared to a more holistic aspirational approach (to develop one's career as well as one's personality), and again juxtaposed to those that are more typically labelled as quality of life factors (notably an overall life context that goes beyond what individual income can buy). We sought to test how these three types of motivations weigh on the 
individual's decision before the onset of the crisis and after 2009, when the crisis started weighing heavily on southern European labour markets.

Figure 6: Reasons for leaving, original options reduced to 5 groups

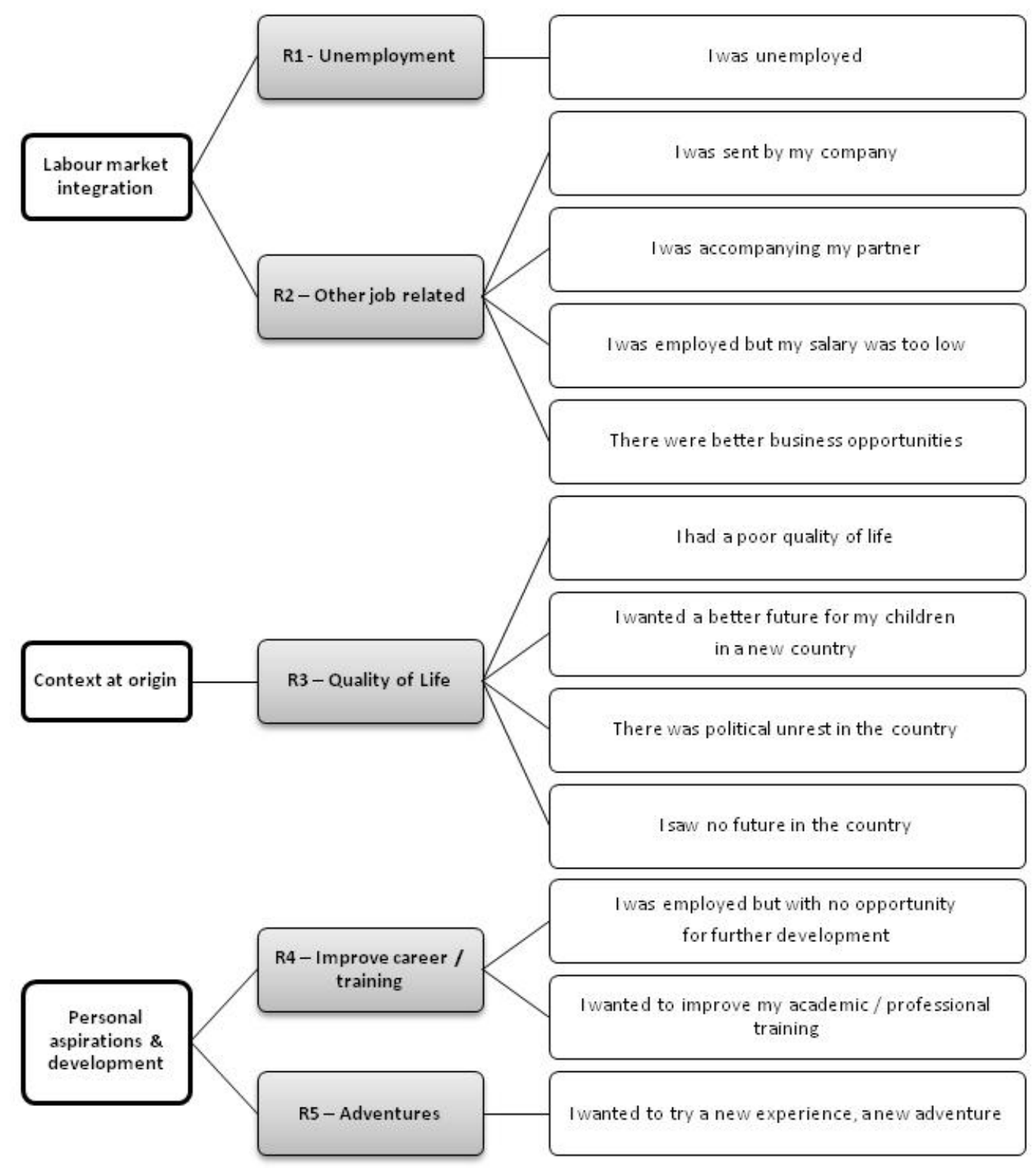

Source: Authors’ compilation from survey data, Highly Skilled Migration in Times of Crisis (2013).

Even through this process, the resulting dichotomous variables for the 5 reasons are partly overlapping and not mutually exclusive for many respondents. Taking these as concurrent reasons for the decision to leave the origin country, we first looked at how they have changed for those emigrated before and during the economic crisis. After running a Chi-squared test between each reason and the time of migration ${ }^{1}$, we can reject with a high level of significance the hypothesis of independence between each reason and the time of migration in all cases but one (Table 4).

\footnotetext{
1 The Chi-squared test measures the level of association or independence between pairs of categorical variables. For the way it is constructed, larger samples give larger Chi2 statistics.
} 
Table 4: Chi2 test for reasons and time of migration (before 2009, since 2009)

\begin{tabular}{llll}
\hline R1 - Unemployment & Pearson chi2(1)=183.0022 & $\operatorname{Pr}<0.000$ & $* * *$ \\
R2 - Other job related reasons & Pearson chi2(1) $=18.7988$ & $\operatorname{Pr}<0.000$ & $* * *$ \\
R3 - Quality of life & Pearson chi2(1) $=101.4005$ & $\operatorname{Pr}<0.000$ & $* * *$ \\
R4 - Improve career / training & Pearson chi2(1) $=2.0698$ & $\operatorname{Pr}=0.150$ & \\
R5 - Adventures & Pearson chi2(1) $=32.6647$ & $\operatorname{Pr}<0.000$ & $* * *$ \\
\hline
\end{tabular}

Significance: $* * * 1 \%$

Source: Authors’ compilation from survey data, Highly Skilled Migration in Times of Crisis (2013).

Indeed, the will and need to improve the professional career or to advance in training - what we label as personal improvement and aspirations - are time-invariant and very important in determining the migration event. Hence, our Chi squared test makes possible to compare the rate of positive responses to each reason for those who emigrated before 2009 and those who migrated from 2009 onwards.

\section{Figure 7: Reasons for emigration, by time of migration (\%, multiple answers possible)}

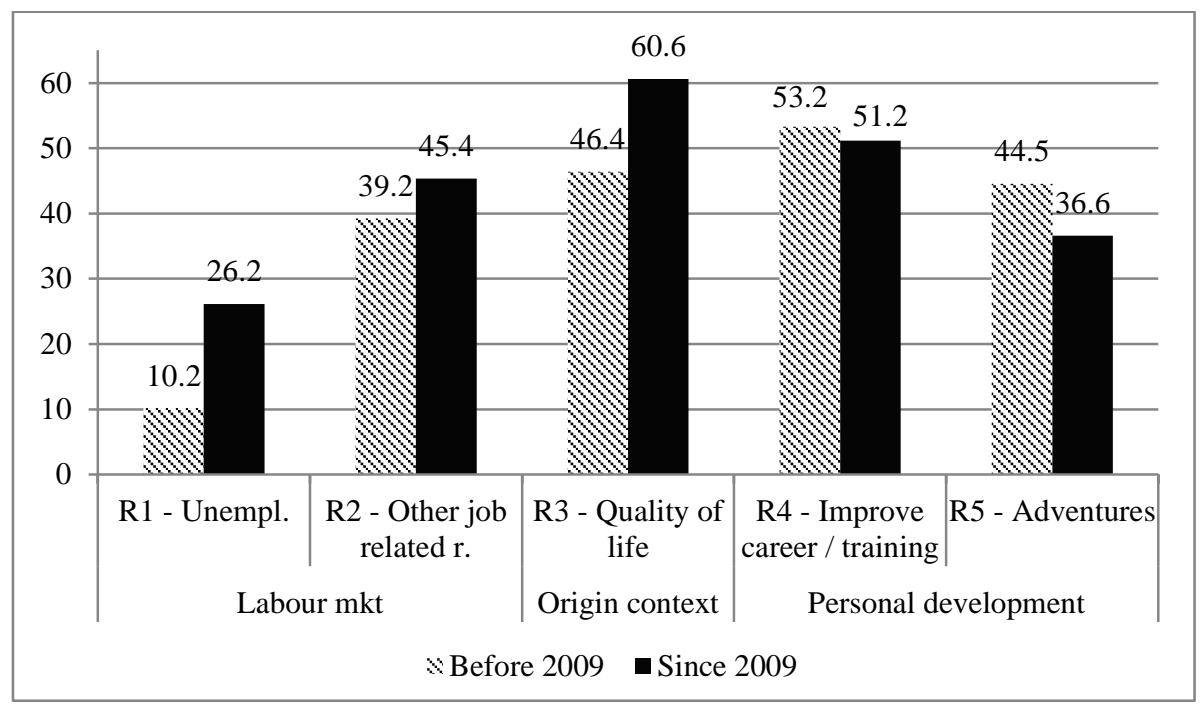

Figure 7 illustrates well the changes in reasons through time. While the willingness to improve career or training is the most common reason among those who left before 2009 and remains important also for those who emigrated since 2009 onwards (53.2 and 51.2\% of respondents respectively), reasons connected to the quality of life and the conditions of the country of origin surge to $60.6 \%$ among those who left during the crisis. Unemployment per se is the less frequently mentioned reason for leaving. Nonetheless it is mentioned most frequently by those who emigrated since 2009 compared to those who emigrated before the crisis (with a significant increase from $10.2 \%$ to $26.2 \%$ of respondents). “Adventurers” decrease among those who left recently compared to those who emigrated before the crisis. In sum, both economic and lifestyle motivations are more prominent for those who left during and after the crisis, while motivations related to personal 
development and individual aspirations are either stable (improve career / training) or actually diminish (adventures).

In the next section we try to disentangle how the described patterns vary according to a set of individual characteristics. Hence, we divide the sample between those who emigrated before 2009 and those who left the origin country from January 2009 onwards. Indeed those who emigrated before and after 2009 are likely to form two distinct groups with reference to their main demographic features as well as to the economic and social context from which they decided to move. For each of these two sub-samples, we explore the correlation between the reasons for migration and some meaningful variables. In particular we focus on bivariate relations which show the more significant Pearson's correlations and prove to vary more between the two time periods.

\section{Sex, Age and Marital Status}

While we found slight differences between men and women in terms of reasons to leave, with women being more likely to move for career or training improvements ${ }^{2}$, differences in terms of age are more evident. In line with what one would expect, younger respondents are more driven by personal development reasons than those over 30, with the majority of them being interested in improving their training or career and/or in doing a new experience abroad in line with what we would expect for young adults (Figure 8).

This is consistent with results distinguished by marital status: single respondents tend to put more emphasis on reasons connected to personal development (career or training improvement as well as adventures), while those in a couple are more likely to claim job-related reasons for migration (moved within the same company or following their partner's job) (Figure 9).

Figure 8: Reasons by age
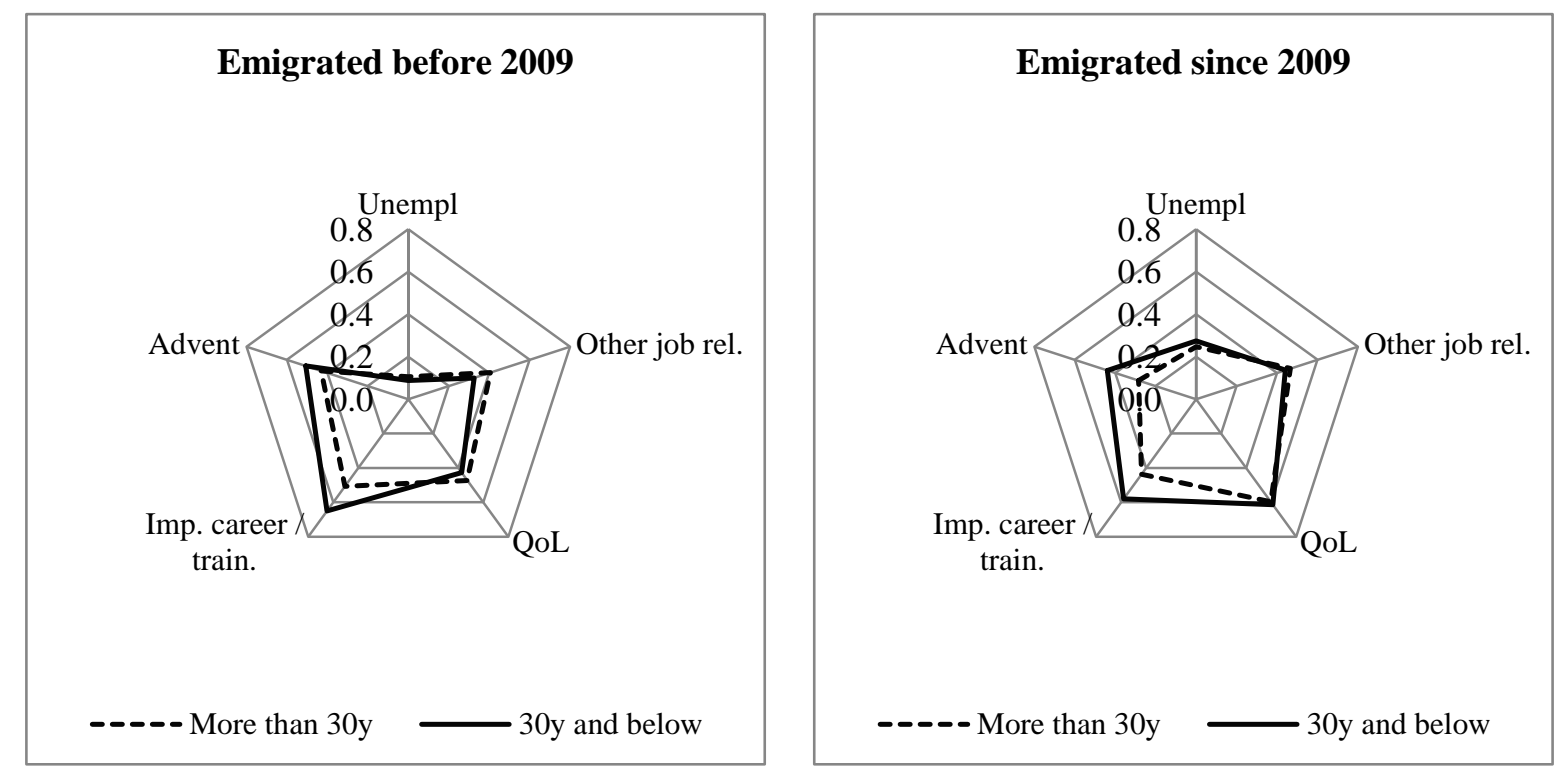

\footnotetext{
${ }^{2}$ Not shown here for the sake of conciseness.
} 


\begin{tabular}{|c|c|c|c|c|c|c|c|c|}
\hline & \multicolumn{4}{|c|}{ Before 2009} & \multicolumn{4}{|c|}{ Since 2009} \\
\hline R1 & Pearson chi2(1) $=$ & 0.8284 & $\operatorname{Pr}=0.363$ & & Pearson chi2(1) & $=4.4826$ & $\operatorname{Pr}=0.034$ & $*$ \\
\hline R2 & Pearson chi2(1) $=$ & 6.7954 & $\operatorname{Pr}=0.009$ & $* *$ & Pearson chi2(1) & $=2.8465$ & $\operatorname{Pr}=0.092$ & \\
\hline R3 & Pearson chi2 $(1)=$ & 2.0778 & $\operatorname{Pr}=0.149$ & & Pearson chi2(1) & $=1.3016$ & $\operatorname{Pr}=0.254$ & \\
\hline R4 & Pearson chi2(1) $=$ & 20.4872 & $\operatorname{Pr}<0.001$ & $* * *$ & Pearson chi2(1) & 97.5064 & $\operatorname{Pr}<0.001$ & $* * *$ \\
\hline R5 & Pearson chi2 $(1)=$ & 5.5537 & $\operatorname{Pr}=0.018$ & $*$ & Pearson chi2(1) & $=120.8004$ & $\operatorname{Pr}<0.001$ & $* * *$ \\
\hline
\end{tabular}

Figure 9: Reasons by marital status

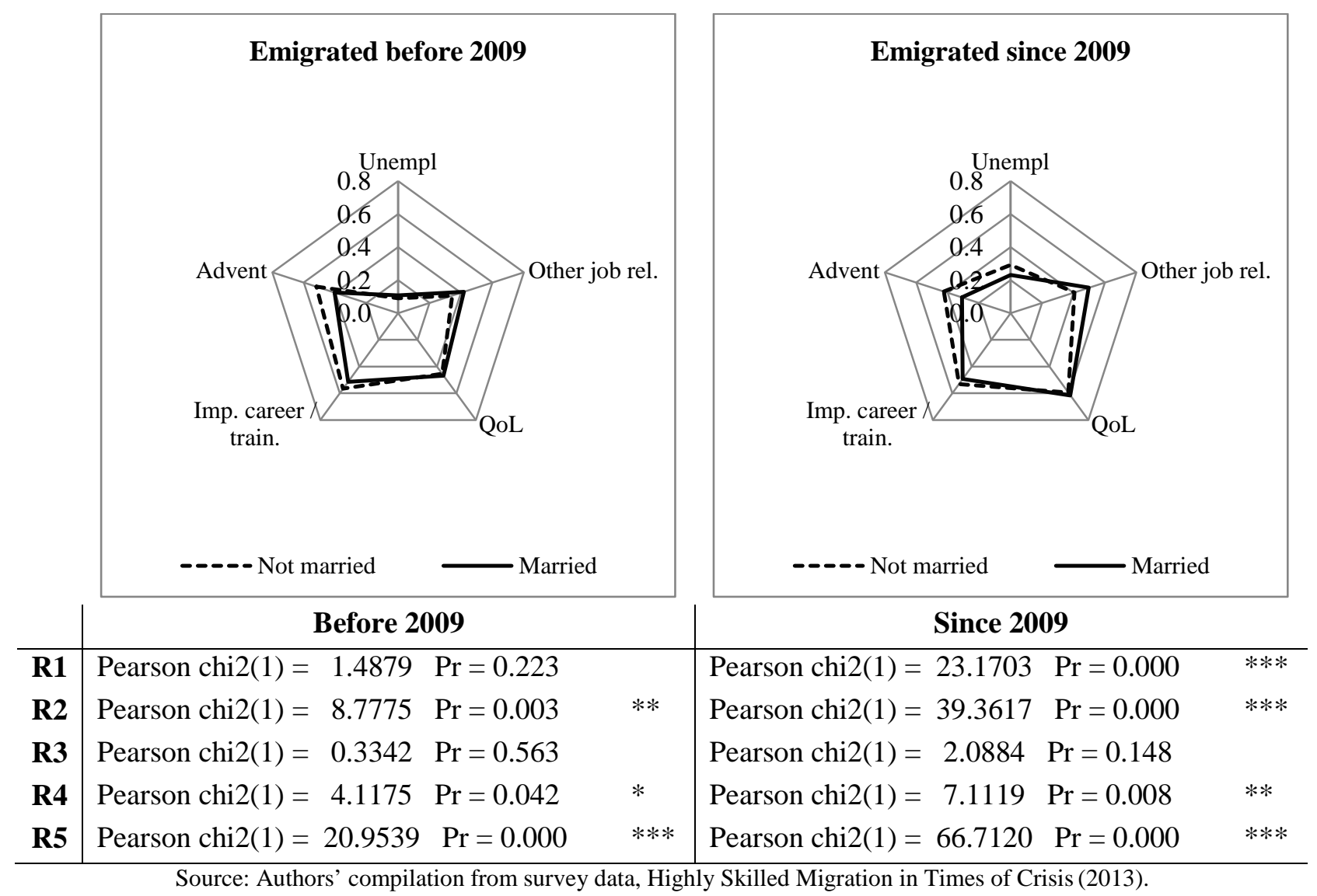

\section{Level of education}

As already presented in Table 2, the large majority of our sample has a high level of education, with only $12 \%$ of the total without tertiary education. Differences in the reasons for leaving vary according to the highest level of education attained (some of the respondents were still in education at the time of the survey) both before 2009 and since.

Figure 10: Reasons by education level 


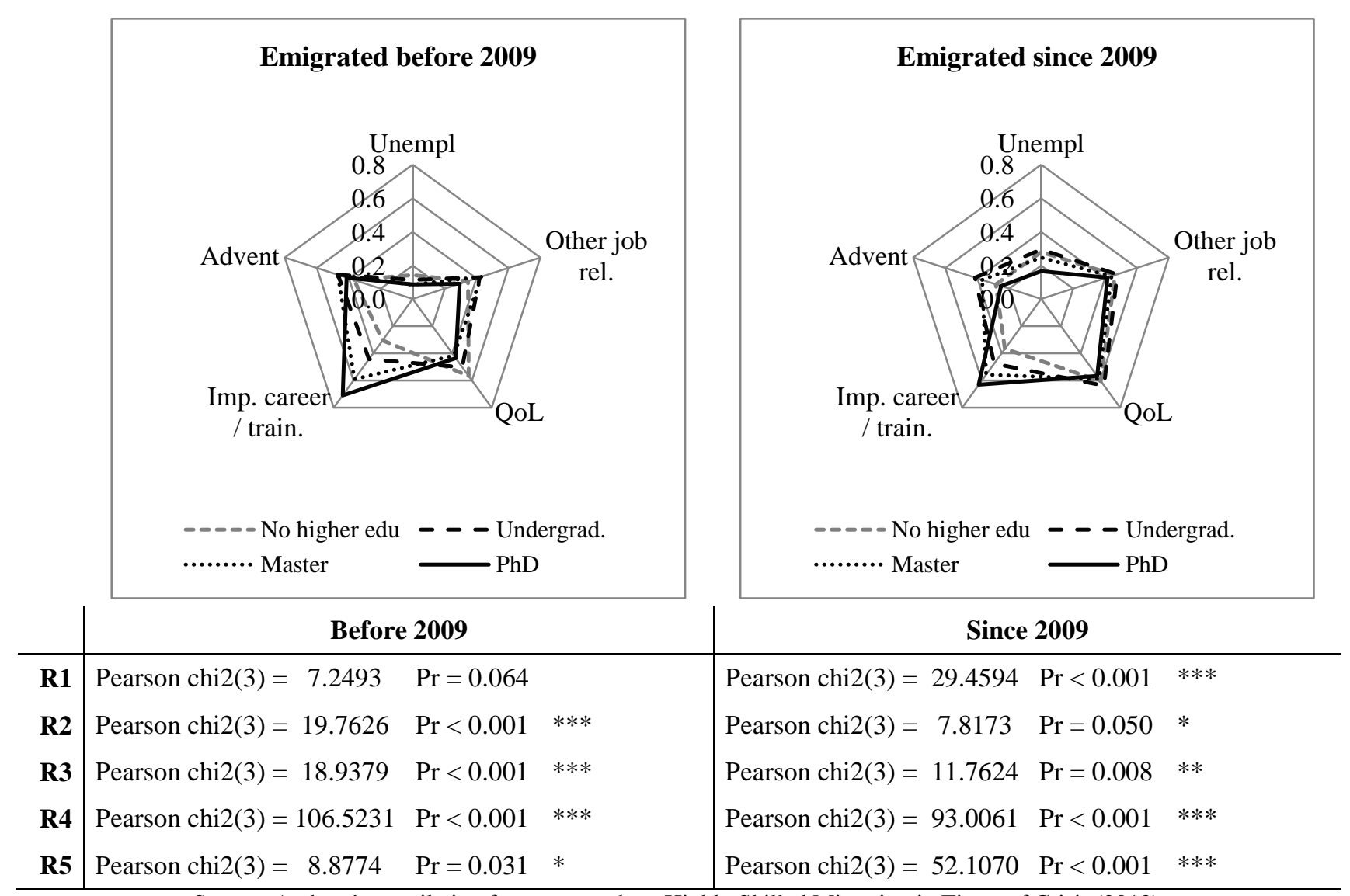

Source: Authors’ compilation from survey data, Highly Skilled Migration in Times of Crisis (2013).

In particular, unemployment becomes a prominent reason for leaving only for those who left in 2009 or later, particularly for those with no higher education or only with a bachelor degree. Also the reasons related to the quality of life and the conditions at origin seem to matter more for the lower educated. On the contrary, the willingness to improve training or career grows with the level of education, with those with a $\mathrm{PhD}$ referring to these reasons more than twice in comparison with undergraduate and non-higher educated respondents. Those with a bachelor or a master degree are most likely to refer to adventures and new experiences, which might be related to a period of break before completing the transition from education to the labour market.

To summarize, respondents with higher levels of formal education, be they men or women, are more likely to look for better career and training opportunities, more meritocratic conditions at the workplace and a better overall quality of life through emigration, while those with lower levels of qualifications refer more often to economic motivations in the strict sense. Economic reasons are more relevant overall for those who emigrated during the crisis, and this is particularly so for those partnered/married, as plans for family formation may require more attention to the economic sustainability of emigration and job related choices. These findings are in line with other recent studies (Cairns 2014). Naturally in a future study we would need to compare these findings with those of a control group with a view to investigating the propensity to leave and not just the motivations. 


\section{Employment status before migration}

Nearly two thirds of the total sample was employed before leaving the country of origin and among those not employed there were both unemployed and those still in education. Distinguishing among those working with no contract, with a short-term contract and with a long-term, open-ended one allows us to compare their actual status before migration to what they mentioned as reasons for migrating.

Job related reasons (too low salary and moving within a company, among other things) are frequently mentioned by those without contract and by those with a long-term one. Those employed without contract also mentioned quality of life and conditions of the origin countries more often, while those with short-term positions are more likely to look for an improvement of their career/training path. While short-term contract's holders try to improve their 'employability' through more training and further steps in the career than long-term ones, Figure 11 shows a clear increase in the prominence of unemployment related reasons for those emigrated after 2009.

Figure 11: Reasons by employment condition before migration

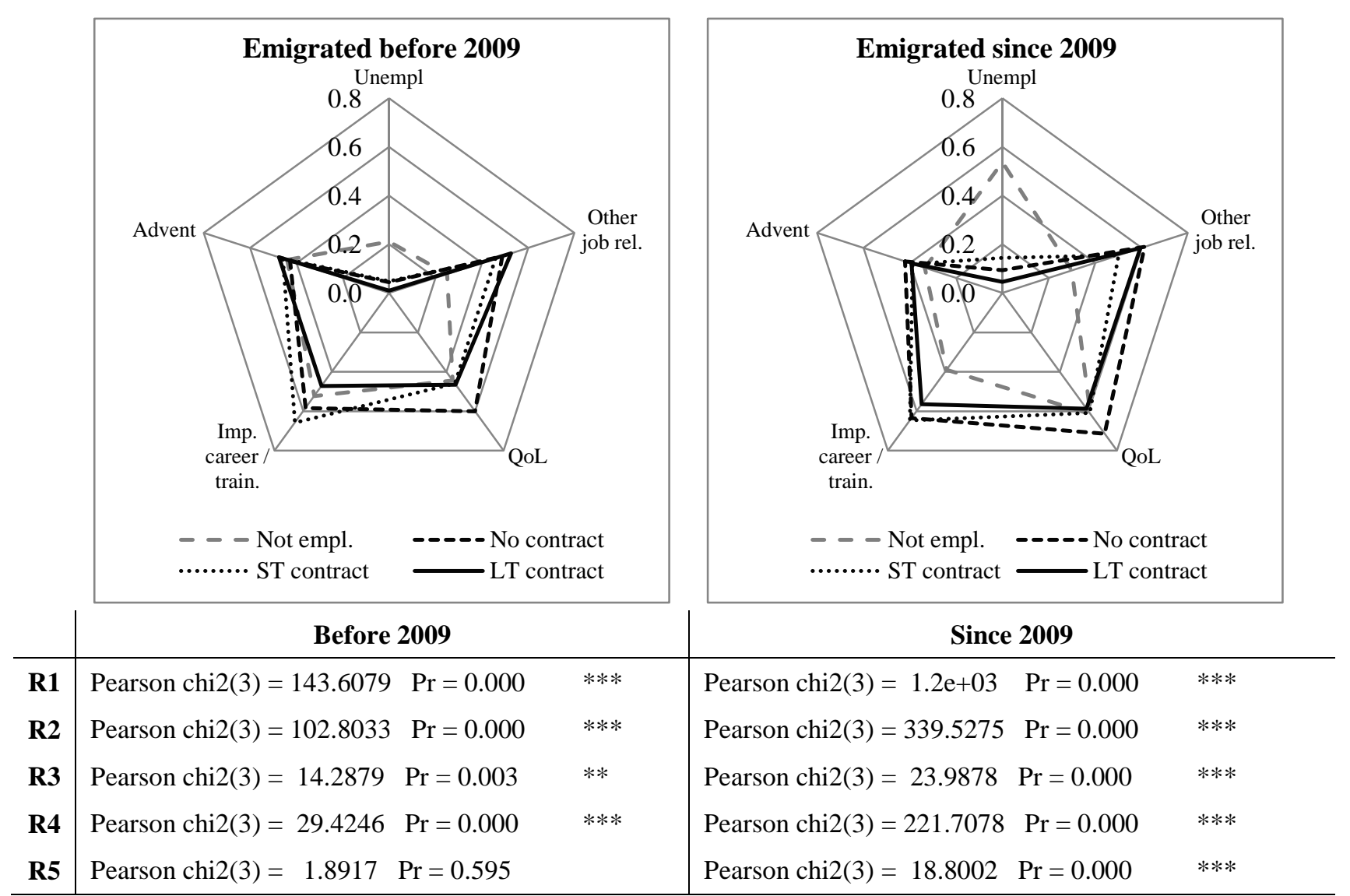

Source: Authors’ compilation from survey data, Highly Skilled Migration in Times of Crisis (2013). 


\section{Country of origin}

To conclude our comparisons of reasons for leaving by specific individual variables, we plot in Figure 12 the differences by country of origin. While unemployment is a primary concern for Spanish and Portuguese respondents, particularly since 2009, Italians and Greeks claimed in half of the cases reasons related to the job they already had, and to the need to improve their training or career paths. Portuguese and Greeks are less satisfied with the quality of life and the situation of their country of origin, while there is a big portion of Portuguese that at any time moved to follow their aspirations to new experiences and adventures. Indeed a striking finding here is that Greeks are less worried about actual unemployment than they are about future prospects.

This may seem paradoxical, it is however easy to explain if we take into account that our respondents are highly skilled people. They are thus concerned not just about their immediate work situation, but about their future and the short to medium term prospects. It is clear that such prospects are particularly bleak in Greece thus making highly skilled people worried for their future and pushing them to seek better opportunities abroad. The strength of adventures and aspirations for new experiences among the Portuguese is in line with the fact that the country was an emigration country even prior to the crisis. Third, in the case of Italians, while unemployment is a lesser concern, it is clear that there is a significant fear that the national economy and labour market are on moving sand and may easily deteriorate

Figure 12: Reasons by country of origin

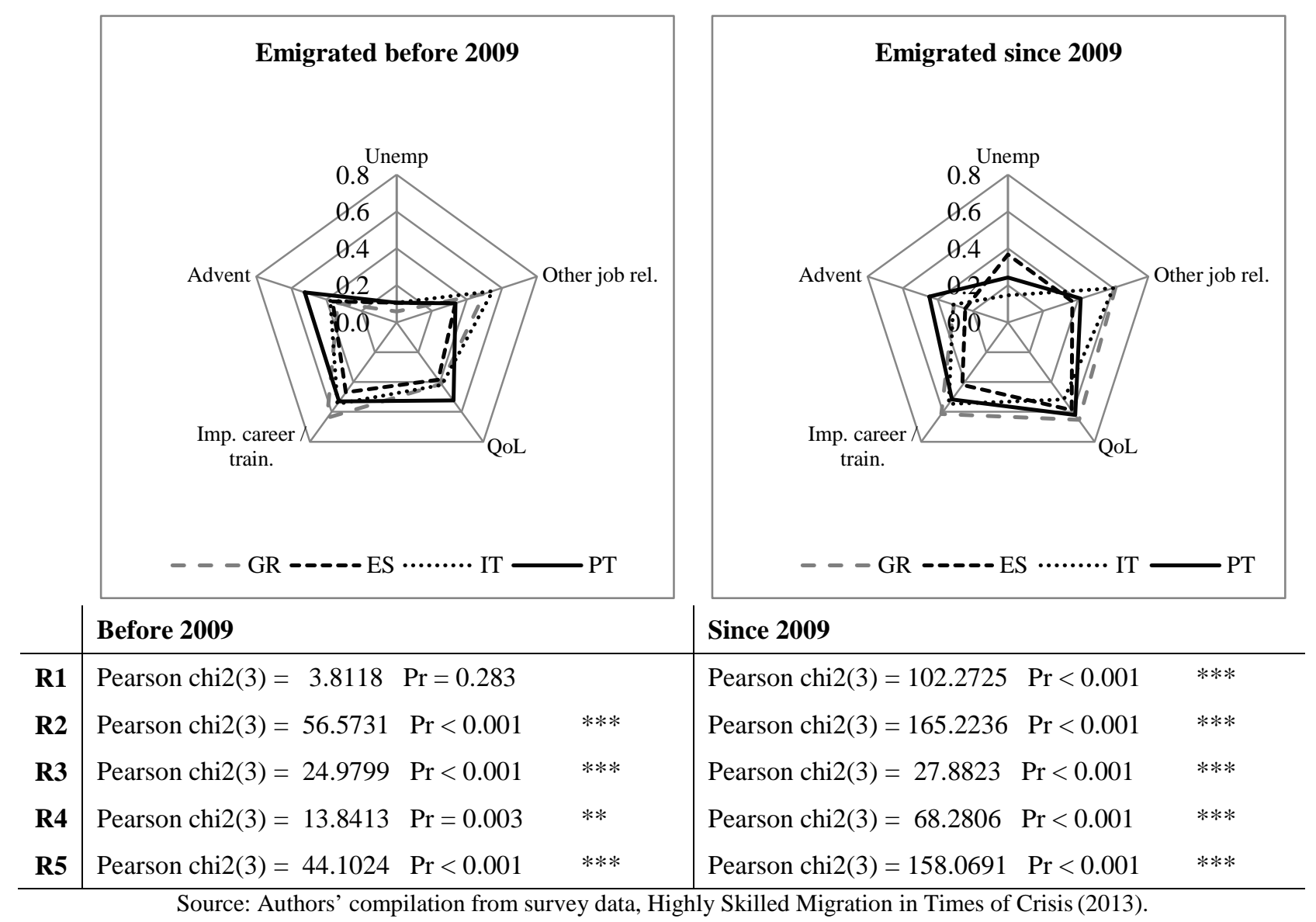




\section{Concluding remarks}

Around the world, migration patterns have become increasingly diversified and we are consistently noting increasingly complex relationships between factors identified as drivers of migration. The current emigration from Southern European countries is different from earlier emigration movements from these countries during the twentieth century ${ }^{3}$. Those who are currently leaving are highly educated in their overwhelming majority and they do not follow cultural networks in their choice of destination country. Their decision to move to a specific country is the result of a combination of factors. It has to do with the push factors of their country of origin (related to both the causes and the consequences of the crisis) and specifically the employment conditions and prospects that they face as well as the political culture of their country of origin that they strongly criticise (clientelism, corruption, nepotism, rigid social hierarchies and gerontocracy).

This paper has explored the factors that concurrently affect the decisions of highly skilled individuals to emigrate paying special attention to changes in these factors for those emigrating under acute recession conditions, notably since 2009. We have used our survey data of highly skilled Greeks, Italians, Portuguese and Spaniards to examine the extent to which the European crisis context - and particularly its effects on unemployment - and the wider background of increased uncertainty and individualization of work and life-time choices, interplay with people's desire for self-emancipation, accumulation of cultural capital and, quite simply, their employment needs.

Unemployment and youth unemployment have increased to unprecedented levels during the economic crisis that began in 2008. Experiencing unemployment or very precarious conditions of work at the beginning of one's working life has important 'scarring' effects. ${ }^{4}$ Long-term joblessness imposes costs on both individuals and the society well into the future: it reduces lifetime earnings, increases the probability of unemployment periods and of precarious employment conditions in the future, it is associated with poorer health and wellbeing conditions through the working life, especially for the young (Bell and Blanchflower 2011).

In this context, we have tried to identify whether the motivations to emigrate have changed after the outbreak of the economic crisis and whether the salience of economic motivations has increased due to the unfavourable economic context after 2008 in all considered countries. Indeed, 'escaping' through emigration appears like a good option especially for highly skilled individuals who have invested in their education and training and wish to see a 'return' on their investment. For welleducated Southern Europeans heading towards other EU countries, this escape is facilitated by the right to free movement within the European Union. Yet, as we have illustrated through the survey data presented above, economic reasons are far from being the exclusive, or even the predominant driver of their migration. Non-economic reasons are in all cases just as important. The desire to improve one's training and career perspective, as to increase employability and individual satisfaction from occupation, is mentioned by more than half of our respondents in all countries.

\footnotetext{
${ }^{3}$ The same has been claimed in the case of Ireland: (Cairns 2014; Glynn, Kelly, and Mac Einrí 2015).

${ }^{4}$ This is not to deny of course that protracted unemployment has scarring effects also on middle-aged workers and makes their return into employment difficult.
} 
The strongest emigration potential appears to lie with those who are dissatisfied with the quality of life and their job prospects at the home country and who refuse to renounce what they think they could/ should achieve in terms of life style and overall satisfaction.

With regard to the impact of the economic crisis on reasons for leaving, we note that it strengthens all factors with the exception of adventures/new experiences. Both financial and professional development reasons gain importance (unemployment or other work related reasons).

For those who emigrated during the last years, reasons related to the possibilities their origin country offers in terms of life style, stability for the future of their children and overall quality of life gained special prevalence suggesting that highly skilled individuals think more long term and have the luxury perhaps to choose not only in terms of imminent needs and unemployment but also to plan ahead in terms of career prospects and financial stability.

Interestingly our study marks no important gender differences in the reasons for emigrating: both men and women surveyed in all four countries are motivated by economic considerations but equally so by non-economic motives that fall within what is generally referred to as post-materialist concerns, notably lifestyle choices, and professional emancipation with a view to achieving a sense of personal fulfilment along with economic stability.

Naturally a direct link between economic recession and reasons to move is difficult to establish, as the latter are formed out of the interplay between individual and family characteristics and contingent labour market conditions. Only longitudinal data would allow us to disentangle the effects of historical times - living and working during an age of economic crisis and austerity - and of life-time stages - being in a couple, forming a family, and so on.

Finally, our findings refer to a selected population of emigrants from Southern European countries. Although we cannot claim a generalization for all emigrants under the same individual and countryspecific circumstances, our data reveal that the EU factor is not perceived per se as facilitator for emigration by respondents. Indeed, a non-negligible share of them migrated outside Europe and beyond the space of free movement granted by the European Union. Moreover, either because of under-perception of the importance of having an EU citizenship or because at high education levels visa issues are more easily solved, few of them explicitly acknowledged the importance of visa facilitation in determining their country of destination.

To be more specific on the changes in patterns of emigration for highly skilled individuals in a context of prolonged economic crisis, and especially within the specific institutional EU context, further research and different data structures are needed. Systematic information either along longitudinal lines or on the group of emigrants and non-emigrants would provide some insightful results on the way individual characteristics and aspirations at young ages interplay with changes in the economic and institutional setting over time. 


\section{References}

Arslan, Cansin, Jean-Christophe Dumont, Zovanga Kone, Yasser Moullan, Caglar Ozden, Christopher Parsons, and Theodora Xenogiani. 2014. "A New Profile of Migrants in the Aftermath of the Recent Economic Crisis.” OECD Social, Employment and Migration Working Papers. Paris: Organisation for Economic Co-operation and Development. http://www.oecd-ilibrary.org/content/workingpaper/5jxt2t3nnjr5-en.

Barro, R.J., and W. Lee. 2013. “A New Data Set of Educational Attainment in the World - 19502010.” Journal of Development Economics 104 (September): 184-98.

Beck, Ulrich. 1992. Risk Society: Towards a New Modernity. Theory, Culture \& Society (Unnumbered). London: Sage.

Beck, Ulrich, and Elisabeth Beck-Gernsheim. 2002. Individualization. Institutionalized Individualism and Its Social and Political Consequences. Sage.

Bell, David N. F., and David G. Blanchflower. 2011. "Young People and the Great Recession.” Oxford Review of Economic Policy 27 (2): 241-67. doi:10.1093/oxrep/grr011.

Blossfeld, Hans-Peter, Jan Skopek, Moris Triventi, and Sandra Buchholz, eds. 2015. Gender, Education and Employment. An International Comparison of School-to-Work Transitions. Edward Elgar Publishing.

Brown, Phillip, Anthony Hesketh, and Sara Williams. 2004. The Mismanagement of Talent: Employability and Jobs in the Knowledge Economy. Oxford University Press. https://books.google.it/books?hl=en\&lr=\&id=twrJS3VeR3sC\&oi=fnd\&pg=PR7\&dq=Brow $\mathrm{n}+$ and+Hesketh+2004\&ots=G35ehAe1HC\&sig=_J64JTubZG5YC4jCOMBVm9yiEnQ.

Cairns, David. 2014. “'I Wouldn’t Stay Here’: Economic Crisis and Youth Mobility in Ireland.” International Migration 52 (3): 236-49. doi:10.1111/j.1468-2435.2012.00776.x.

Campanella, Edoardo. 2015. “Come Home, Europeans. Europe’s Brain Drain Problem Is Becoming a Major Crisis.” Foreign Affairs. Accessed November 18. https://www.foreignaffairs.com/articles/europe/2014-10-16/come-home-europeans.

de Grip, Andries, Didier Fouarge, and Jan Sauermann. 2010. "What Affects International Migration of European Science and Engineering Graduates?” Economics of Innovation and New Technology 19 (5): 407-21. doi:10.1080/10438590903434828.

European Commission. 2010. “Geographical and Labour Market Mobility.” Eurobarometer 337 Report. Brussels: DG Employment, European Commission.

. 2013. "Intra-EU Mobility of Third-Country Nationals.” European Migration Network Study. Brussels: DG Home Affairs, European Commission. http://ec.europa.eu/dgs/homeaffairs/doc_centre/immigration/docs/studies/emn-

synthesis_report_intra_eu_mobility_final_july_2013.pdf.

Eurostat. 2015a. European Union Database. http://ec.europa.eu/eurostat/data/database.

2015b. Labour Force Survey (Online Database), Retrieved from Http://ec.europa.eu/eurostat/web/lfs/ Data/database. 
EY. 2014. "Evaluation of the Impact of the Free Movement of EU Citizens at the Local Level Final Report.” Brussels: DG Justice, European Commission. http://ec.europa.eu/justice/citizen/files/dg_just_eva_free_mov_final_report_27.01.14.pdf.

Fassio, Claudio, Sona Kalantaryan, and Alessandra Venturini. 2015. "Human Resources and Innovation: Total Factor Productivituy and Foreign Human Capital.” RSCAS Working Paper 2015/43. Florence: European University Institute. http://hdl.handle.net/1814/36236.

Fassio, Claudio, Fabio Montobbio, and Alessandra Venturini. 2015. “How Do Native and Migrant Workers Contribute to Innovation? A Study on France, Germany and the UK.” 9062. IZA Discussion Papers. IZA. http://ftp.iza.org/dp9062.pdf.

Frändberg, Lotta. 2015. “Acceleration or Avoidance? The Role of Temporary Moves Abroad in the Transition to Adulthood.” Population, Space and Place 21 (6): 553-67. doi:10.1002/psp.1851.

Fratesi, Ugo, and Massimiliano R. Riggi. 2007. "Does Migration Reduce Regional Disparities? The Role of Skill-Selective Flows.” Review of Urban \& Regional Development Studies 19 (1): 78-102. doi:10.1111/j.1467-940X.2007.00125.X.

Giddens, Anthony. 1991. Modernity and Self-Identity. Self and Society in the Late Modern Age. Stanford, California: Stanford University Press.

Glynn, Irial, Tomás Kelly, and Piaras Mac Einrí. 2015. “The Re-Emergence of Emigration from Ireland: New Trends in An Old Story.” Migration Policy Institute. http://www.migrationpolicy.org/research/reemergence-emigration-ireland-new-trends-oldstory.

Gropas, Ruby, and Anna Triandafyllidou. 2014. "Integration, Transnational Mobility and Human, Social Nad Economic Capital - Concept Paper for the ITHACA Project.” ITHACA Research Report N. 1/2014. ITHACA Project. Florence: European University Institute. http://cadmus.eui.eu/handle/1814/31200.

ILO. 2014. “Skills Mismatch in Europe : Statistics Brief.” Geneva: International Labour Office. . 2015. “Global Employment Trends for Youth 2015: Scaling up Investments in Decent Jobs for Youth.” Report. Geneva: International Labour Office. http://www.ilo.org/global/research/global-reports/youth/2015/WCMS_412015/lang-en/index.htm.

Jauer, Julia, Thomas Liebig, John P. Martin, and Patrick A. Puhani. 2014. "Migration as an Adjustment Mechanism in the Crisis? A Comparison of Europe and the United States.” IZA Discussion Paper 7921, February. http://papers.ssrn.com/abstract=2389289.

Labrianidis, Lois. 2014. "Investing in Leaving: The Greek Case of International Migration of Professionals.” Mobilities 9 (2): 314-35. doi:10.1080/17450101.2013.813723.

Labrianidis, Lois, and Nikos Vogiatzis. 2013. "Highly Skilled Migration: What Differentiates the 'Brains' Who Are Drained from Those Who Return in the Case of Greece?” Population, Space and Place 19 (5): 472-86. doi:10.1002/psp.1726. 
Massey, Douglas S., Joaquin Arango, Graeme Hugo, Ali Kouaouci, Adela Pellegrino, and J. Edward Taylor. 1993. "Theories of International Migration: A Review and Appraisal." Population and Development Review 19 (3): 431-66. doi:10.2307/2938462.

Mathiassen, Rikke. 2014. “Expert: Erasmus Programme Is Causing 'Brain Drain.” Euroscope. September $10 . \quad$ http://publications.europeintheworld.com/expert-student-exchangeencourages-young-brains-flee-southern-europe/.

Mosneaga, Ana. 2014. "Student Migration at the Global Trijuncture of Higher Education, Competition for Talent and Migration Management.” In Indian Skilled Migration and Development, edited by Gabriela Tejada, Uttam Bhattacharya, Binod Khadria, and Christiane Kuptsch, 87-111. Dynamics of Asian Development. Springer India. http://link.springer.com/chapter/10.1007/978-81-322-1810-4_5.

OECD. 2013a. Database on Immigrants in OECD Countries 2010/2011. http://www.oecd.org/els/mig/dioc.htm.

—. 2013b. International Migration Outlook 2013. Paris: OECD Publishing. http://dx.doi.org/10.1787/migr_outlook-2013-en.

O’Reilly, Jacqueline, Werner Eichhorst, András Gábos, Kari Hadjivassiliou, David Lain, Janine Leschke, Seamus McGuinness, et al. 2015. "Five Characteristics of Youth Unemployment in Europe Flexibility, Education, Migration, Family Legacies, and EU Policy.” SAGE Open 5 (1): 2158244015574962. doi:10.1177/2158244015574962.

Papademetriou, Demetrios G. 2015. "Rethinking Emigration - Turning Challenges into Opportunities.” Council Statement. Washington, D.C: Migration Policy Institute.

Parey, Matthias, and Fabian Waldinger. 2011. "Studying Abroad and the Effect on International Labour Market Mobility: Evidence from the Introduction of ERASMUS*.” The Economic Journal 121 (551): 194-222. doi:10.1111/j.1468-0297.2010.02369.x.

Raffini, Luca. 2014. “Quando La Generazione Erasmus Incontra La Generazione Precaria. La Mobilità Transnazionale Dei Giovani Italiani E Spagnoli.” OBETS: Revista de Ciencias Sociales, no. 9: 130-66.

Recchi, Ettore. 2015. Mobile Europe. The Theory and Practice of Free Movement in the EU. Palgrave Macmillan.

Recchi, Ettore, and Justyna Salamońska. 2015. "Bad Times, Good Times to Move? The Changing Landscape of Intra-EU Migration.” In Europe's Prolonged Crisis. The Making or the Unmaking of a Political Union, by Hans-Jörg Treens, Carlo Ruzza, and Virginie Guiraudon, 124-47. Palgrave Macmillan.

Schwab, Klaus. 2016. The Fourth Industrial Revolution. World Economic Forum.

Souto-Otero, Manuel, Jeroen Huisman, Maarja Beerkens, Hans de Wit, and SunČica VujiĆ. 2013. "Barriers to International Student Mobility Evidence From the Erasmus Program." Educational Researcher 42 (2): 70-77. doi:10.3102/0013189X12466696.

Waters, Johanna, Rachel Brooks, and Helena Pimlott-Wilson. 2011. "Youthful Escapes? British Students, Overseas Education and the Pursuit of Happiness.” Social \& Cultural Geography 12 (5): 455-69. doi:10.1080/14649365.2011.588802. 
Waters, Johanna L. 2012. "Geographies of International Education: Mobilities and the Reproduction of Social (Dis)advantage.” Geography Compass 6 (3): 123-36. doi:10.1111/j.1749-8198.2011.00473.x. 